\title{
Ortaokul 8. Sınıf Öğrencilerinin Demokratik Değer Algılarının Karikatürler Aracılı̆̆ılyla İncelenmesi ${ }^{1}$
}

\section{An Investigation of 8th Grade Students' Perceptions of Democratic Values Through Cartoons}

\author{
Erkan Dinç, Doç. Dr., Uşak Üniversitesi Eğitim Fakültesi Sosyal Bilgiler Eğitimi, erkandinc@gmail.com \\ Servet Suna Üztemur, Doktora öğrencisi, Uşak Üniversitesi Sosyal Bilgiler, servetuztemur@gmail.com
}

\begin{abstract}
ÖZ. Bu çalışmanın amacı ortaokul 8. sınıf öğrencilerinin eşitlik, adalet, özgürlük ve dayanışma değerlerine ilişkin algılarını karikatürler aracılığıyla ortaya koymaktır. Nitel araştırma yöntemi temelinde keşfedici araştırma modeline göre desenlenen araștırmanın çalışma grubunu 2014-2015 öğretim yılında Manisa ili Yunusemre ilçesindeki bir devlet ortaokulunun 8. sınıf öğrencileri oluşturmaktadır. Araştırmanın birinci aşamasında gönüllü 60 öğrenciye her birinden üçer tane olmak kaydıyla ele alınan dört değere ilişkin karikatürler verilerek bunları ilgili değerlerle eşleştirmesi istenmiştir. İkinci aşamada öğrencilerin demokratik değer algılarının ayrıntılı analizi için karikatür yorumlama etkinliği yapılmıștır. Araştırma bulgularına göre öğrenciler en fazla adalet ve eşitlik değerlerini birbirine karıștırmışlardır. Özgürlük karikatürünün yorumlanmasında öğrencilerin zorluk yaşadığı görülmüştür. Araştırma sonucuna göre öğrenciler, adaletin eşitlikten daha iyi olduğunu ve adil bir yaşam için bazı insanlara pozitif ayrımcılık yapılması gerektiğini belirtmiş; özgürlük değerini düşünce özgürlüğü ve bağımsız hareket etme şeklinde algılamış; eşitlik değerini paylaşma, açgözlü olmama, elindekilerle yetinme ve uyum içinde yaşama kategorileriyle açıklamış; dayanışma değerinde işbirliği, birlik ve beraberlik, haksızlığa karşı çıkma ve yardımlaşmanın önemine vurgu yapmıştır.
\end{abstract}

Anahtar Kelimeler. Demokratik değerler, Karikatürler, Değer algısı, 8. Sınıf öğrencileri

ABSTRACT. This study aims to investigate eight grade students' perceptions of some democratic values through the use of cartoons. The values under examination are equality, justice, freedom and solidarity. Designed as an explorative qualitative study, this work intends to describe and discuss the participants' perceptions on some values. The study group consists of 60 grade eight students attending to public school in Manisa province in 2014-2015 academic year. At the first phase of the study, all students in the study group were given a matching exercise. Then they were asked to match each cartoon in their worksheets to the relevant democratic value. At the second phase, it was requested from students to associate each given cartoon to relevant democratic value and then interpret and evaluate her/his reasoning behind each association they made. The findings reveal that more than half of the students intermixes the values of justice and equality. They also experienced difficulties in interpreting the cartoons related to freedom. The findings also indicate that students perceive justice as a more important and useful value than equality. Some of them defended that in order to achieve at more fair social life standards, it is necessary to practice positive discrimination against some disadvantaged individuals or groups. Besides, most participants perceived freedom mostly to freedom of thought and freedom of action, while a sizeable group associated the value of equality with sharing, not being greedy, to be contended and congenial. In relation with the value of solidarity, the students emphasized on collaboration, cooperation, helping each other and resisting injustice. Keywords. Democratic values, Cartoons, Perception of values, Grade 8 students

\section{SUMMARY}

Purpose and Significance: The democratization of societies requires generating and regenerating democratic values and culture in families and schools as its preconditions. The accommodation of a democratic culture in schools perquisites the adoption of more democratic attitudes by administrators, teachers, students, parents and other school stakeholders. The aim of democratic education is to raise new generations as individuals who are thinking critically and reflectively, selfimproving, quick witted, respectful to the diversity of thoughts, sensitive to and reacting against injustice and unfair situations, advocating justice, equality and freedom and having necessary social participation skills to work for the common good. The aim of this study is to examine grade eight

${ }^{1}$ 5-7 Kasım 2015 tarihinde düzenlenen II. Uluslararası Katılımlı Değerler Eğitimi Kongresinde sunulmuş sözlü bildirinin yeniden düzenlenip genişletilmiş halidir. 
students' perceptions of democratic values through the use of cartoons. The research question under investigation could be stated as "How grade eight students perceive the values of justice, freedom, equality and solidarity?"

Methodology: This work was designed as an exploratory qualitative study. The study group was consisted of 60 grade eight students attending to a public secondary school in Manisa province in 2014-2015 academic year. At the first phase of the study, all students in the study group were given a matching exercise. Then they were asked to match each cartoon in their worksheets to the relevant democratic value. At the second phase, it was requested from 40 students, who were selected from the initial study group on the basis of volunteering, to associate each given cartoon to relevant democratic value and then interpret and evaluate her/his reasoning behind each association they made. A content analysis technique was applied to the available data through which students' interpretations and reasoning were repeatedly coded and categorized.

Results: The findings revealed that the proportion of students' accurately matching cartoons with the relevant values is $60,97 \%$. Besides, having trouble in understanding and interpreting the cartoons about justice in both activity, more than half of the students intermixed the values of justice and equality. Moreover, the findings indicated that students perceive justice as a more important and useful value than equality. It was found out that most students easily comprehended the main theme or message of the cartoons, while some of them experienced difficulties in interpreting the cartoons related to freedom. Some students defended that in order to achieve at more fair social life standards, it is necessary to practice positive discrimination against disadvantaged individuals or groups. Furthermore, most participants perceived freedom mostly as freedom of thought and freedom of action, wheras a sizeable group associated the value of equality with sharing, not being greedy, to be contended and congenial. In relation with the value of solidarity, the students emphasized on collaboration, cooperation, helping each other and resisting injustice

Discussion and Conclusions: In conclusion, it could be stated that cartoons are useful tools to utilize in examination of individuals' and groups' value perceptions. They are not only helping the participants to remember and focus on their inner feelings and thoughts but also dispatching them to make sense of what they see in a frame and interpret it. Another conclusion that was reached at this study is that apart from having trouble in intermixing the values of justice and equality, about $60 \%$ of students could ably distinguish and locate those democratic values under investigation and provide their reasoning. Finally, it was seen that the participants' perceptions of democratic values found out are consistent with the results of previous studies in the relevant literature.

\section{GÍRIŞ}

Günümüz bilgi ve teknoloji toplumunda bireyin önemi her geçen gün artmakta bunun sonucunda eğitim faaliyetleri çağın koşullarına uygun olacak biçimde bireyin ilgi ve yetenekleri dikkate alınarak yenilenmektedir. Eğitim sürecinin en temel amacı bireylerde bilişsel, duyuşsal ve devinişsel alanda istendik yönde davranış değişikliği yaratmaktır. Bireyin gelişiminde bu üç alanın hepsinin ayrı bir önemi olmasına rağmen bilişsel alana daha fazla önem verildiği görülmektedir (Bacanll, 2006; Givens, 2010; McNeill, Burrows \& Bellamy, 2000; Uygun ve Engin, 2014). Eğitimin amacı sadece bilgi ve beceri kazandırmak değil; aynı zamanda değișen dünya koşullarına ayak uydurabilen, kendi kişisel özelliklerini ve yakın çevresini tanıyan ve topluma uyum sağlamış bireyler yetiştirmek olmalıdır (Ada ve Ünal, 2000; Naml, 2015). Buradan hareketle her toplum hem kendine özgü hem de evrensel değerleri eğitim aracılığıyla kişilere aktarmayı görev edinmiștir.

Yeşil ve Aydın (2007: 70) değer kavramını, "insanın herhangi bir varlık ya da olaya bakış açısını ve verdiği önemi yansıtan, benimseme esasına dayalı, davranışlara yön verme gücüne sahip psikolojik, sosyal, ahlaki ve estetik boyutlu inanç ve kanaatler bütünü" olarak tanımlamışlardır. Erdem'e (2003) göre değerler bireylerin kendilerince önem atfettikleri şeyler, tercihler ve seçimlerdir. Tutum ve davranışların ve bireyin toplumdaki yerinin belirlenmesinde önemli bir yere 
sahip olan değerler davranışlarımıza kılavuzluk eden inanç ve kurallar bütünüdür (Hökelekli, 2010; Kulaksızoğlu ve Dilmaç, 2000; Yazıcı, 2006). Değerler doğuştan getirilmeyip sonradan edinilir. Toplum tarafından önemli kabul edilen değerlerin bireylere öğretimi eğitim sayesinde olur ve değer öğretiminde eğitimcilere çok büyük görev düşmektedir. Öğretilmesi gereken değerlerin arasında ise demokratik değerler önemli bir yere sahiptir.

Demokratik değerler açısından eğitimin en temel hedefi; demokrasinin bilgi, beceri ve değerlerini benimseyen, bunu yaşam biçimine dönüştürmüş, siyasi rol ve sorumluluklarının bilincinde, yaptıklarının sonuçlarını düşünen, toplumun gelişmesine katkıda bulunan aktif bireyler yetiştirmektir (Sarı ve Sadık, 2011). Dewey (2010) toplumda demokratik anlayışın oluşturulma sürecinde okulların çok büyük bir öneme sahip olduğunu belirtmiştir. Demokratik bir okul ortamı da eğitimin kalitesini artırır. Bu nedenle demokrasinin tam anlamıyla işe koşulması için eğitim seviyesi yüksek insanlara ihtiyaç vardır. (Karakütük, 2001: 14). Çağdaş, demokratik düşünme yeteneğine sahip, sorumluluklarının farkında olan, olaylara çok yönlü bakabilen, hoşgörülü bireyler yetiştirmenin birinci adımı eğitim sisteminin demokratik olmasından geçer (Celep, 1995: 20).

Toplumda demokratikleșme bilincinin yerleșmesi, önce ailede daha sonra okullarda demokrasi kültürünün oluşmasından geçmektedir. Karakütük'e (2001: 14) göre bir toplumda demokrasinin tam anlamiyla uygulanabilmesi için devlet, okul ve ailenin ișbirliği içinde birbirlerini desteklemeleri gerekmektedir. Özpolat'a (2010: 366) göre demokratik bir eğitim demokrasiyi öğretmeli, eğitimin hedef, politika, program, mevzuat, materyal, okul kültürü ve öğretim uygulamaları aşamalarında demokrasiyi rehber edinmelidir. Demokratik eğitimin amacı eleştirel ve yansıtıcı düşünme becerilerine sahip, kendini geliştiren ve yenileyen esnek zekâlı, farklı düşüncelere saygıyla yaklaşan, haksızlıklar karşısında tepkisini ortaya koyan duyarlı, adalet ve eşitliği savunan özgürlüğüne düşkün, sosyal katılım becerilerini kullanarak toplumun refahı için emek harcayan bireyler yetiștirmektir (Moller, 2006). Demokratik değerleri benimsemiş ve bunları yaşam biçimine dönüştürmüş bireyler hem kendilerinin hem de toplumun mutlu ve huzurlu olmasına katkı sağlayacak ve toplumda barış ve adalet temin edilecektir (Toomey, 2010: 33).

Demokratik eğitimle birlikte öğrencilerde özgür düşünme, tartışma, eleştirme, farklı fikirlere saygı duyma, hoşgörülü olma ve fikirler arasında anlaşmaya varma sağlanmalıdır. Bu etkinliklerle yoğrulan öğrenciler demokratik tutum ve davranışları yaşam biçimine dönüştürme konusunda bir adım önde yer alır (Yeşil, 2003). Okulların demokrasi kültürüne tam anlamıyla katkı sağlayabilmesi için Doğanay ve Sarı (2006: 2) üç boyutta düzenleme yapılması gerektiğini vurgulamışlardır. Yazarlara göre birincisi öğretim programının içeriğinde demokrasi, ikincisi sınıf içerisinde demokrasi ve son olarak da okulun bir bütün olarak demokrasinin temel ilkelerinin uygulandığı ve demokratik değerlerin yaşandığı bir ortam olarak düzenlenmesidir. Demokrasinin sadece derslerde bilgi olarak öğretilip sınıfta ve okul ortamında uygulamaya geçirilmemesi öğrencilerin tam anlamıyla demokratik değerleri benimsemesinin önünde bir engel olarak karşımıza çıkmaktadır (Doğanay ve Sarı, 2006: 2). Öğrenme sırasında, öğrencinin öğrenme etkinliğini kısıtlayan, yeteneklerinin geliştirilmesine izin vermeyen, öğretmen ve yönetici otoritesinin hâkim olduğu bir okulda, öğrencilerin demokratik davranışlar sergilemesi mümkün değildir. Demokratik eğitimde öğrencilerde kalıplaşmış davranış örüntüleri ve ezberlemeye dayalı bir anlayıştan ziyade; yaratıcı düşünme ve sorun çözmeye dayalı öğrenmelere olanak veren, öğrendiklerini yorumlayabilen ve yeni durumlara aktarabilen öğrenciler yetiștirmek temel esastır (Celep, 1995: 23). Demokratik okul deyince demokrasinin içerik olarak öğrenilmesinden ziyade bizzat okul paydaşları tarafından uygulamada yaşatılması akla gelmelidir (Doğanay ve Sarı, 2006: 2).

İlgili alanyazın incelendiğinde demokratik değerlerin; adalet, eşitlik, özgürlük, şiddetten kaçınma, insan haklarına saygı, hoşgörü, ifade özgürlüğü, çoğulculuk olarak kabul edildiği görülmektedir (Kıncal ve Işıı, 2003; Kışlalı, 1994; Tanilli, 1995; Yeşil, 2002). Cılga'ya (2001) göre özgürlük, adalet ve eşitlik demokrasinin temel bileşenleridir. Aynı şekilde Novak (1994) ve Osler ve Starkey (1994) gibi araştırmacılar da demokrasinin temel kavramlarının adalet, eşitlik ve özgürlük olduğunu belirtmişlerdir (akt., Karadağ, Baloğlu ve Yalçınkayalar, 2006). Büyükkaragöz ve Üre (1994) demokratik tutumu; kişilerin firsat ve imkân eşitliği, özgürlük ve adalet gibi temel değerleri kanunlarla belirlenen çizgiler içerisinde bir yaşam tarzı olarak hayata geçirdiği 
davranışlar bütünü şeklinde tanımlamışlardır. Yukarıda belirtildiği gibi en temel demokratik değerler; özgürlük, adalet ve eşitlik olarak kabul edilmektedir.

Ülkemizde demokratik değerler ve demokratik eğitim ilgili yapılan çalışmalara bakıldığında teorik çalışmalar (Başaran, 1986; Güven ve Akkuş, 2004; Hotaman, 2010; Okutan, 2010; Özpolat, 2010; Şişman, Güleş ve Dönmez, 2010; Yeşil ve Aydın, 2007) ve öğretmen adaylarına yönelik çalışmaların (Akın ve Özdemir, 2009; Aydemir ve Aksoy, 2010; Ektem ve Sünbül, 2011; Gömleksiz ve Kan, 2008; Sarı ve Sadık, 2011; Yazıcl, 2011) yaygın olduğu görülmektedir. Ortaokul öğrencilerine yönelik yapılan araştırmalar (Doğanay ve Sarı, 2004; İlğan, Karayiğit ve Çetin, 2013; Kaldırım, 2003; Kaya, 2006; Mulhan, 2007; Sabancı, 2007; Ural ve Sağlam, 2011; Uygun ve Engin, 2014; Yüksel, Bağcı ve Vatansever, 2013) incelendiğinde nicel ve betimsel çalışmaların yaygın olduğu görülmekte, nitel çalışmaların azlığı dikkat çekmektedir.

Alanyazın taramasında ortaokul öğrencilerinin demokratik değer algılarının nitel araștırma yöntemiyle incelendiği iki çalışmanın sonuçları aşağıda özetlenmiştir. Nayır ve Akar (2009) tarafından yapılan nitel araştırmada beşinci sınıf öğrencilerinin özgürlük kavramına ilişkin algıları incelenmiştir. Araştırma bulgularına göre öğrenciler özgürlüğü her istediğini yapabilme olarak algılamakta ve özgürlüğü bașkalarına zarar vermeme ve davranıșlarında serbestlik olarak tanımlamaktadır. Araștırmacılar öğrencilerin özgürlük tanımlarında saygı, hak ve sorumluluk gibi kavramları kullanmadıklarına ve șiddeti özgürlük alanı içine dâhil ettikleri sonucuna varmışlardır. Ortaokul öğrencilerin demokratik değer algılarının incelendiği bir diğer nitel araştırmada (Yılmaz, 2013) öğrencilerin sorumluluk, hak, eşitlik, vatandaşlık ve egemenlik değerlerine ilişkin algıları öğrencilerle yapılan mülakatlar aracılığıyla ayrıntılı bir şekilde ortaya konulmuştur. Araştırmanın sonuçlarına göre öğrenciler sorumluluk ve hak kavramlarını yanılgıya düşmeden doğru tanımlamalarına rağmen vatandaşlık ve egemenlik gibi kavramları tanımlarken zorlanmış ve başka kavramlarla karıştırmışlardır. Öğrenciler eşitlik değerini doğru tanımlamış ve din, dil, ırk vb. farklılıklara bakmaksızın herkesin eşit haklara sahip olması gerektiğine vurgu yapmışlardır.

Gerek nitel araştırmaların azlığı gerekse demokratik değer algılarının ayrıntılı bir şekilde incelenmesi için bu araştırmada ortaokul 8. sınıf öğrencilerinin demokratik değer algıları karikatürler aracllığıyla belirlenmeye çalışılmıştır. Türk Dil Kurumu sözlüğüne (1998: 1220) göre, "İnsan ve toplumla ilgili her tür olayı konu alarak abartılı bir biçimde belirten, düşündürücü ve güldürücü resim" olarak tanımlanan karikatürler öğrencilerin sözel sorgulama, yazma, çizme, anlama, fark etme, tartışma ve üst düzey düşünme becerilerinin gelişmesinde çok önemli bir yere sahiptir (Sidekli, Er, Yavaşer ve Aydın, 2014). Karikatürler öğrencilerde karşılaştırma, eleștirel ve yansıtıcı düşünme becerilerini geliştirerek duygu ve düşüncelerini sözlü ve yazılı olarak anlatabilmelerine, çevresini ve içinde yaşadığı toplumu daha iyi tanımlamalarına olanak sağlar (Uslu, 2007: 16). Öğrencilerin demokratik değer algılarının belirlenmesinde ve tartışmalı konularda sınıf içi tartışma becerilerinin gelişiminde karikatürler işlevsel bir öğretim aracıdır. Sosyal meselelerin incelenmesinde kullanılan karikatürler, güncel siyasi, teknolojik, toplumsal değer ve normların eleştirel bir bakışı açısıyla incelenmesine olanak sağlar. Bundan dolayı karikatürlerin değer eğitiminde hem öğrenme hem de değerlendirme aşamalarında kullanılması faydalı olacaktır (Ersoy, 2010: 82).

Dördüncü ve beşinci sınıf öğrencilerinin değer algılarını karikatür aracılığıyla incelemek amacıyla Ersoy (2010) tarafından yapılan araștırmada öğrencilere dayanışma değeriyle ilgili bir karikatür verilmiş yorumlamaları istenmiștir. Araștırmada karikatürlerin sosyal içerikli değer ve normlara ilişkin kazanımlarda bir durum belirleme aracı olarak kullanılabileceği sonucuna ulaşılmıştır. Bu durumdan hareketle bu araştırmanın amacı ortaokul 8. sınıf öğrencilerinin demokratik değer algılarını karikatürler aracılığıyla derinlemesine incelemektir. Araştırmada “Ortaokul 8. sınıf öğrencileri adalet, özgürlük, eşitlik ve dayanışma değerlerini nasıl algılamaktadır?" sorusuna yanıt aranmıștır. 


\section{YÖNTEM}

\section{Araştırma Deseni}

Ortaokul 8. sınıf öğrencilerinin demokratik değer algılarının belirlenmesi amacıyla bu çalışma nitel araştırma yöntemi temelinde keşfedici araştırma modeline göre desenlenmiştir. Keşfedici araștırma, incelenen konu hakkında alanda neler olup, bittiğini, hangi durum ve faaliyetlerin gerçekleștiğini, katılımcı ya da paydaşların ne tür tutum, algı, inanç, görüș ve yargılara sahip olduklarının erken bir tespitini yapmaya yarayan nitel bir araștırma modelidir (Maxwell, 2008; Singh, 2007). Bu çalışmanın başlıca araştırma sorusu da 8. sınıf öğrencilerinin bazı demokratik değerleri nasıl algıladıklarını ortaya çıkarmak olduğundan bu modelin uyarlanması tercih edilmiştir.

\section{Çalıșma Grubu}

Araştırmanın çalışma grubunu 2014-2015 öğretim yılı Manisa ili Yunusemre ilçesindeki MEB ortaokulunun sekizinci sınıfında okuyan 60 öğrenci oluşturmaktadır. Öğrencilerin seçiminde kolay ulaşılabilir durum örneklemesinden yararlanılmıştır. Kolay ulaşılabilir durum örneklemesi, çoğu zaman araştırmacıların diğer örnekleme yöntemlerini kullanma fırsatının olmadı̆̆ı durumlarda kullanılır (Yıldırım ve Şimşek, 2013: 141).

\section{Verilerin Toplanması ve Çözümlenmesi}

Araştırmada veri toplama süreci iki aşamada gerçekleșmiştir. Birinci aşamada çalışma grubunun tamamını oluşturan 60 öğrenciye araştırma kapsamında yer alan adalet, özgürlük, eşitlik ve dayanışma değerleriyle ilgili her birinden üçer tane olmak üzere toplamda on iki karikatür verilerek bunları ilgili değerlerle eşleştirmeleri istenmiştir. Karikatürlerin seçiminde Sosyal Bilgiler eğitimi bölümünden üç öğretim üyesinden uzman görüşü alınmıştır. Ayrıca öğrencilerin okulundaki Vatandaşlık ve Demokrasi Eğitimi dersine giren iki Sosyal Bilgiler öğretmenine danışılarak karikatürlerin öğrencilerin seviyesine uygunluğu teyit edilmiştir. Çalışma grubundan ayrı olarak on öğrenciyle pilot çalışma yapılmış ve karikatürlerin öğrencilerin seviyelerine uygun olduğu kanısına varılmıştır. Eşleștirme sonuçları çözümlenerek frekans ve yüzde olarak gösterilmiştir.

Veri toplama sürecinin ikinci aşamasında karikatür-değer eșleștirmesi yapan öğrencilere araştırma kapsamındaki her bir değerle ilgili bir karikatür verilerek bunları çalışma kâğıdına yorumlamaları istenmiştir. Çalışma grubundaki 40 öğrenci araştırmanın ikinci aşamasına gönüllü olarak katılmayı kabul etmiş ve bir ders saati süresince karikatür yorumlama etkinliği yapılmıștır. Çözümlemelere geçmeden önce her bir öğrenciye 1'den 40'a kadar numara verilmiş ve öğrenciler numara sırasına göre kodlanmıştır. Öğrenci yorumları içerik analizine tabi tutularak kodlara ayrılmış ve kodlardan kategorilere ulaşılmaya çalışılmıştır. Kodlama işlemleri araştırmacılar tarafından ayrı ayrı yapılarak görüş birliği ve görüş ayrılığı olan durumlar belirlenerek üzerinde gerekli düzeltmeler yapılmıștır. Miles ve Huberman (1994) tarafından önerilen güvenirlik formülü [p= Görüş birliği / (Görüş birliği + görüş ayrılığı)] hesaplanarak \%91 bulunmuştur. Miles ve Huberman'a (1994) göre bir araştırmanın güvenilir kabul edilmesi için güvenirlik yüzdesinin \%70'in üzerinde olması gerekmektedir. Ayrıca araştırmada inanırlığı artırmak amacıyla öğrencilerin görüşlerinden doğrudan alıntı yapılmıştır.

\section{BULGULAR}

Araştırmanın ilk basamağında öğrencilerin demokratik değer algılarını belirlemek amacıyla karikatür-değer eşleştirmesi yapılmıştır. Öğrencilerin karikatür-değer eşleştirme sonuçları Tablo 1 'de gösterilmiştir.

Tablo 1'de görüldüğü üzere dört değere ilişkin toplamda on iki karikatürün öğrenciler tarafından doğru eşleştirme oranı \% 60,97'dir. Bu sonuçtan öğrencilerin genelinin karikatürlerde anlatılmak istenen ana fikri kavradıkları sonucuna varılabilir. Öğrenciler \% 80 oranla en fazla dayanışma değerine ait karikatürleri doğru eşleştirirken \% 33,88 oranla en az adalet değerine ilişkin karikatürleri doğru eşleştirmişlerdir. Ortaya çıkan matrisin çapraz yorumlaması yapıldığında öğrencilerin en fazla eşitlik ve adalet değerlerini birbirine karıștırdıkları ortaya çıkmıştır. Adalet 
değeriyle ilgili karikatürlere eşitlik cevabını verenlerin oranı \% 63,88 iken öğrencilerin \%42,77'si eşitlik değeriyle ilgili karikatürlere adalet cevabını vermiştir. Öğrenciler \%98,3 oranla en fazla özgürlük değeriyle ilgili dördüncü karikatüre doğru cevap vermişlerdir. En fazla kavram yanılgısına düşülen iki numaralı karikatüre bakıldığında öğrencilerin sadece \%25'inin doğru cevabı eșleștirdiği görülmektedir. Öğrencilerin büyük bir çoğunluğu iki numaralı karikatürdeki adalet değerinin simgesi olan iki eşit teraziyi eşitlik değeriyle karıştırmıştır.

Doğru eşleştirme oranının \% 60,97 olmasına rağmen öğrencilerin karikatürlerde verilmek istenen mesajı anlayıp anlamadıkları ortaya koymak ve çalışma kapsamındaki değerlere yönelik algılarının ayrıntılı çözümlenmesi amacıyla her bir değeri temsilen birer karikatür çalışma grubundaki gönüllü 40 öğrenciye çalışma kâğıdında verilerek yorumlamaları istenmiştir.

Tablo 1. Karikatür-Değer Eşleştirme Matrisi

\begin{tabular}{|c|c|c|c|c|c|c|c|c|c|c|c|}
\hline \multirow{2}{*}{\multicolumn{2}{|c|}{ KARİKATÜRLER }} & \multicolumn{8}{|c|}{ DEĞERLER } & \multirow{2}{*}{\multicolumn{2}{|c|}{ TOPLAM }} \\
\hline & & \multicolumn{2}{|c|}{ ADALET } & \multicolumn{2}{|c|}{ ÖZGÜRLÜK } & \multicolumn{2}{|c|}{ EŞITTLIKK } & \multicolumn{2}{|c|}{ DAYANIŞMA } & & \\
\hline & & $\mathbf{f}$ & $\%$ & $\mathbf{f}$ & $\%$ & $\mathbf{f}$ & $\%$ & f & $\%$ & $\mathbf{f}$ & $\%$ \\
\hline \multirow{3}{*}{ 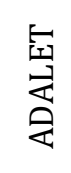 } & Karikatür 1 & 19 & 31,6 & 1 & 1,6 & 39 & 65 & 1 & 1,6 & 60 & 100 \\
\hline & Karikatür 2 & 15 & 25 & - & - & 44 & 73,4 & 1 & 1,6 & 60 & 100 \\
\hline & Karikatür 3 & 27 & 45 & 1 & 1,6 & 32 & 53,3 & - & - & 60 & 100 \\
\hline \multirow{3}{*}{ 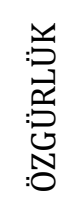 } & Karikatür 4 & - & - & 59 & 98,3 & - & - & 1 & 1,6 & 60 & 100 \\
\hline & Karikatür 5 & 3 & 5 & 47 & 78,3 & 3 & 5 & 4 & 6,6 & 60 & 100 \\
\hline & Karikatür 6 & 13 & 21,6 & 36 & 60 & 9 & 15 & 2 & 3,3 & 60 & 100 \\
\hline \multirow{3}{*}{ 急 } & Karikatür 7 & 36 & 60 & 2 & 3,3 & 18 & 30 & 4 & 6,6 & 60 & 100 \\
\hline & Karikatür 8 & 5 & 8,3 & 3 & 5 & 52 & 86,6 & 1 & 1,6 & 60 & 100 \\
\hline & Karikatür 9 & 36 & 60 & 2 & 3,3 & 22 & 36,6 & - & - & 60 & 100 \\
\hline \multirow{3}{*}{ 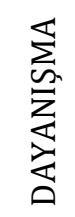 } & Karikatür 10 & 7 & 11,6 & 1 & 1,6 & 7 & 11,6 & 45 & 75 & 60 & 100 \\
\hline & Karikatür 11 & 7 & 11,6 & 7 & 11,6 & 1 & 1,6 & 45 & 75 & 60 & 100 \\
\hline & Karikatür 12 & 3 & 5 & 3 & 5 & - & - & 54 & 90 & 60 & 100 \\
\hline
\end{tabular}

Adalet Karikatürüne Ait Bulgular

Adalet değeriyle ilgili karikatüre dair öğrenci yorumları çözümlenmiş ve Şema 1'deki kod ve kategorilere ulaşılmıştır.

Şema 1. Adalet Karikatürü Yorumlamalarından Elde Edilen Kodlar ve Kategoriler

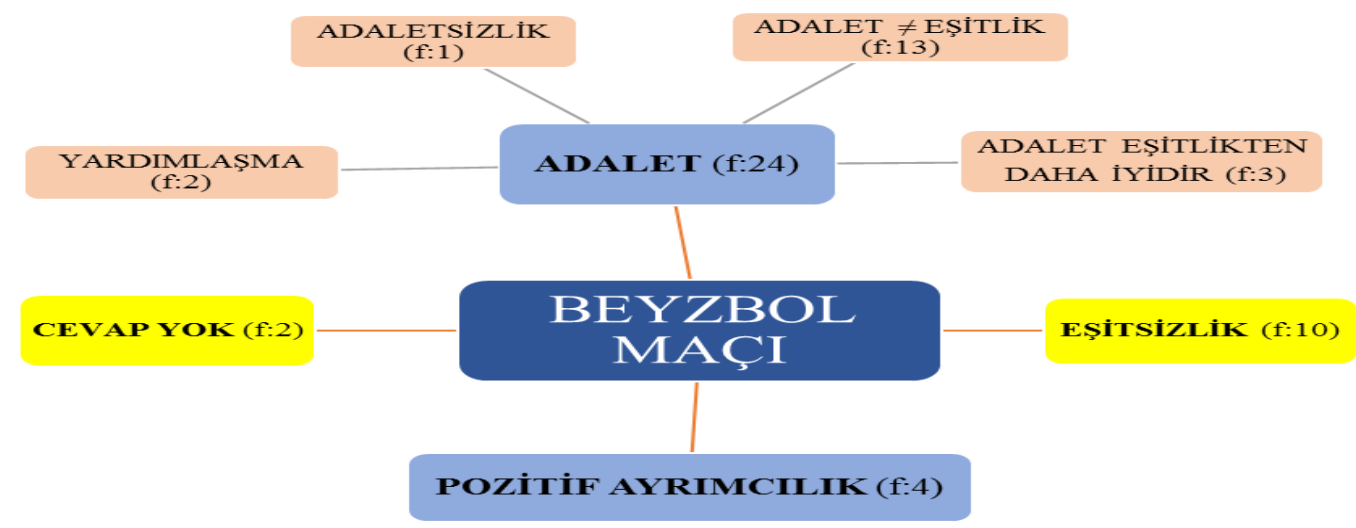


Beyzbol maçı olarak isimlendirilen ve iki bölümden oluşan karikatürde birinci bölümde maç izleyen üç çocuk yer almakta ve her birinin altında birer kutu yer almaktadır. Her çocuğa eşit sayıda kutu verildiği için en kısa boylu olan maçı izleyememektedir. Karikatürün ikinci bölümünde ise üç çocuktan en kısa boylu olan iki kutu üstüne, orta boylu olan bir kutu üstüne çıkmıştır. Uzun boylu olan ise zaten boyu yetiştiği için kutuya çıkmasına gerek yoktur. Karikatürde anlatılmak istenen adaletin eşitlik değerinden farklı olduğunu belirtmektir. Şema 1 incelendiğinde öğrenci yorumlarının adalet, eşitsizlik ve pozitif ayrımcılık adı altında üç ana kategori altında toplandığı görülmüştür. Adalet değeriyle doğrudan ilişkili olmayan kategoriler sarı renkte gösterilmiştir. Öğrencilerin büyük bir bölümünün (f:24) karikatürde verilmek istenen adaletin eşitlikten farklı bir değer olduğu mesajını doğru anladıkları görülmüştür. Adalet ile eşitlik ayrımını kavrayan 21 numaralı öğrencinin ifadesi aşağıdaki gibidir:

"Eşitlik ve adalet farkını anlıyorum. Mesela herkese aynı değeri vermek, seni üzenle üzmeyeni; iyiliğini isteyenle kötülüğ̈̈nü isteyeni bir tutmak eşitliktir. Herkese hak ettiğini vermek, üzmeyenin yanında olup üzeni bırakmak ise adalettir. Herkese adalet uğramalıdır. Suçluya, suçsuza, haklıya, haksıza, iyiye, kötüye yani herkese uğramalıdır."

Yukarıdaki ifadelerden bu öğrencinin adalet değerini hak kavramıyla ilișkilendirerek ifade ettiği ve eşitlik değerinden farklı bir nitelikte olduğunu kavradığını görmekteyiz. Adalet ile eşitlik farkını vurgulayan 15 numaralı öğrencinin ifadesi şu şekildedir.

"Eşitlik ile adalet karıştırılıyor. Eşitlik haklıyı mağdur, haksızı mutlu eder. Adalet haklıyı mutlu, haksızı mutlu eder. Olması gereken budur. Maalesef bazı insanlar bunu ayırt edemiyor ve adalet çürüyor, çürütüyorlar."

Adaletin olması durumunda gerçek eşitliğin olacağını savunan 33 numaralı öğrencinin görüşleri şu şekildedir:

"Birinci resimde eșitlik, ikinci resimde adalet anlatılmaktadır. Eşitlik bazen eșitlik değildir. Böyle istisnalar sonucu insanları kısıtlayabiliriz. Oysaki ikinci resimdeki gibi adalet olduğunda eşitlik meydana gelmiş olur."

Yukarıdaki öğrenci ifadelerinden adaletli bir yaşam sayesinde gerçek eşitliğe ulaşılacağı sonucuna varılabilir. Adalet kategorisi altında yer alan alt kategorileri incelediğimizde öğrencilerin adalet değerini yardımlaşmayla ilişkilendirdiği görülmektedir. Bu duruma 37 numaralı öğrencinin aşağıdaki görüşleri örnek gösterilebilir:

"Bizim ihtiyacımız olmayanı başkalarına verebiliriz. Bencil olmamalıyız. Yardımlaşmalıyız. Adam uzun boylu maçı görüyor hem de altında kutu var. Bu haksızlık. Uzun boylu olan kutuya ihtiyaç duymamalıdır. Yani bizim ihtiyacımız yok ama biz almayıp ihtiyacı olana vermeliyiz."

Öğrenciler adaletin sağlanabilmesi için bazı durumlarda pozitif ayrımcllık yapılması gerektiğini vurgulamışlardır. Pozitif ayrımcılık kategorisine ait görüşlerin bir özeti olarak 1, 6 ve 25 numaralı öğrencinin görüşleri sırasıyla aşağıda sunulmuştur:

"Burada fiziksel özelliklerden bahsediliyor, fiziksel özellikleri yeterli olmayanlara daha çok ayrıcalık verelim ki işini yapabilsinler. Gerçek hayatta da fiziksel imkânları az olan insanlara daha fazla ayrıcalık tanımalıyız. Bazı düşünceli insanlar zaten bunu yapıyor ve ayrıcalık tanıyor. Ayrıcalık tanımayanlar ise çok büyük bir hata yapıyor. Fiziksel engellilere biraz da olsa ayrıcalık tanımalıyız."

"Adalet ve eşitlik birbirleriyle karıştırılsa dahi çok farklı kavramlardır. Aynı koşullar altındaki eşitlik adaleti doğurabilir; fakat eşitlik birçok durumda adaleti bozar. Örnek verecek olursam, bir sınav yapılacak olsun ve bu sınava engelsiz bir öğrenci ile görme engelli bir öğrenci girsin. İki öğrenci eşit şartlarda sınavı tamamlarsa adaletsizlik ortaya çıkar. Deprem çadırlarına yemek dağıtırken dört kişilik bir aile ile sekiz kişilik aileye aynı miktarı vermeniz adaletsiz olur ama eşit davranmış olursunuz. Sözün özü adalet eșitlik değildir."

“....... Büyüklerimize saygıll, küçüklerimize sevgili olmalıyı. Mesela otobüste yolculuk yaptığımız zaman otobüse bizden yaşça büyük olanlara yer vermeliyiz. Yaşlılara, hamilelere ve sakat insanlara bazı konularda yardımcı olmalıyı."

Bazı öğrenciler (f:10) ise adalet ile eşitlik değerlerini birbiriyle karıștırmıştır. Karikatürleri adalet değerine değinmeden sadece eşitliğe vurgu yaparak değerlendirmişlerdir. Bu duruma örnek olarak 35 numaralı öğrencinin aşağıdaki yorumlamaları gösterilebilir:

"Resimde üç tane küpe benzer bir şeyler var. Illk resimde herkese eşit olarak bir tane küp veriliyor. En kısa boylu olan çocuk maçı seyredemiyor. Hâlbuki ikinci resimde olduğu gibi en uzun 
boylu küp almasa en kısa boylu olana verse sorun çözülecek. Boyları eşit olunca rahatlıkla maçı izleyebilecek. Eşitlikten bahsedilmek istenmiştir."

Karikatüre yapılan öğrenci yorumlarının genel bir değerlendirmesi yapıldığında, öğrencilerin büyük bir bölümünün adaletin eşitlikten farklı ve daha iyi olduğunu belirttikleri görülmektedir. Adaletin toplumdaki önemine vurgu yapan yorumlamaların çoğunlukta olduğu görülmektedir. Öğrencilerin bakış açısına göre ideal toplum yapısına adaletin iyi işlemesiyle varılacak ve insanlar arasındaki asıl eşitlik adalet işe koşulduğunda olacaktır.

\section{Özgürlük Karikatürüne Ait Bulgular}

Özgürlük değeriyle ilgili karikatüre dair öğrenci yorumları çözümlenmiş ve Şema 2'deki kod ve kategorilere ulaşılmıştır.

\section{Şema 2. Özgürlük Karikatürü Yorumlamalarından Elde Edilen Kodlar ve Kategoriler}

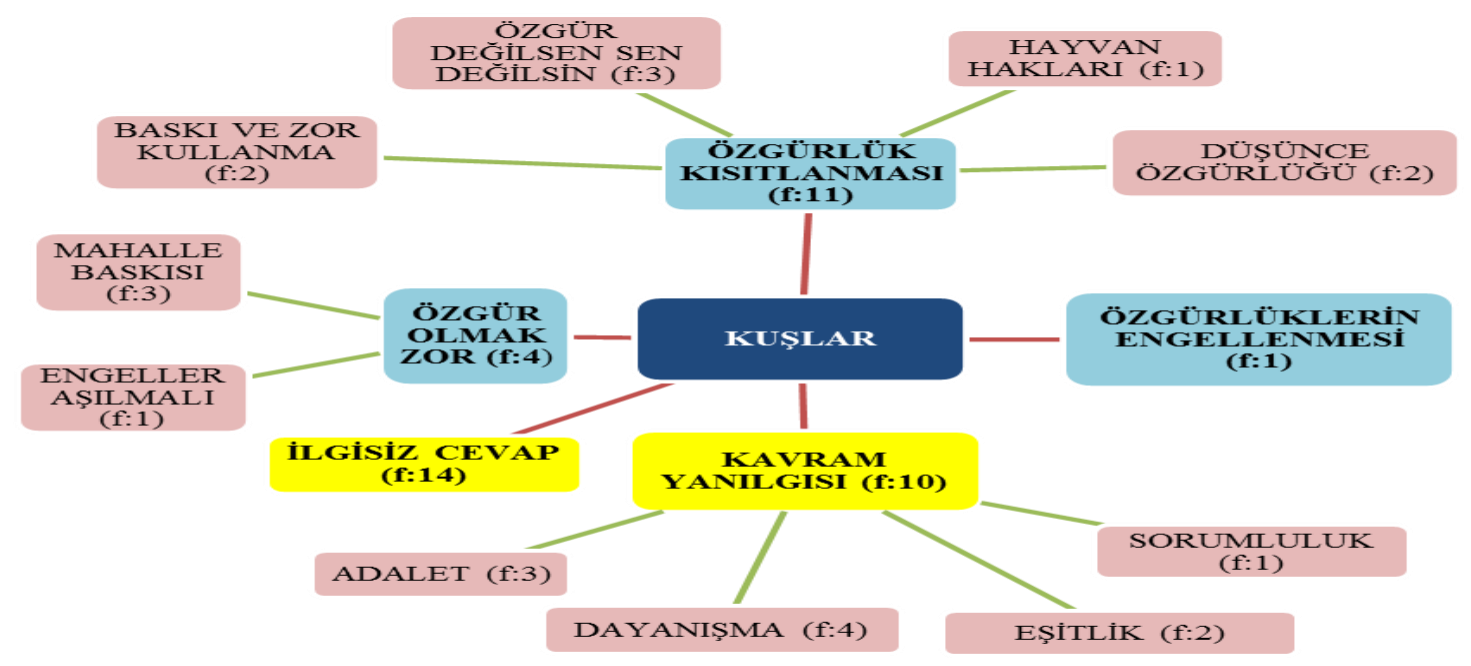

Kuşlar olarak isimlendirilen karikatürde uçan kuşların insanın elindeki bir kalem aracılığıyla özgürlüklerinin elinden alınması ve kuşların bir çizgi ile birleştirilerek tel örgüler oluşturulması anlatılmaktadır. Şema 2 incelendiğinde öğrenci yorumlamalarının özgürlüklerin kısıtlanması, özgürlüklerin engellenmesi, özgür olmanın zorluğu, ilgisiz cevaplar ve kavram yanılgıları adı altında beş ana kategoride toplandığı görülmektedir. Özgürlük değeriyle doğrudan ilişkili olmayan kategoriler sarı renkte gösterilmiştir. Karikatürde anlatılmak isteneni kavrayan öğrenciler özgürlüklerin kısıtlanması ve engellenmesi kategorisi altında görüş bildirmişlerdir. Karikatürü hak ve özgürlükler açısından yorumlayan 6 ve 7 numaralı öğrencilerin görüşleri aşağıdaki gibidir:

"Bu resimde özgürlük hakkı ve yaşama hakkı engellenmiştir. Tüm insanlar eşit ve özgür doğarlar ama hepsinin aynı yerde ve aynı çizgide yaşaması özgürlük ve yaşama hakkını elinden allyor."

"Bu resimde özgürlük anlatıllyor resimde üç tane kuş var ve kaçıyorlar kalem ise onları kovalıyor. Diğerlerinin özgürlüklerini kısıtlamıș"

Özgürlük değerine düşünce özgürlüğü penceresinden bakan 38 numaralı öğrencinin görüşleri şu şekildedir:

"Bu resimden anladığım kuşları bir iple bağlıyor yani özgürlüğünü elinden alıyor. Her insanın başta düşünce özgürlüğü olmak üzere özgürlükleri vardır. Bu özgürlüklerin engellenmemesi gerekir.”

Öğrencilerin bir bölümü özgürlük değerini hayattaki güzelliklerle ilişkilendirmiştir. Bu duruma örnek olarak 3 numaralı öğrencinin görüşleri verilebilir:

"Yukarıdaki bu karikatür bana göre özgür olamamayı anlatıyor. Bunun nedeni o adamın tek çizgiyle bir sürü kuşu elektrik tellerine dönüştürmesidir. Yani bizden büyük birinin emri altında olmak 
gibi bir şey. İster mertebe isterse fiziken senden büyük ya da üstün olması onu ayrıcalıklı kılar ve sen onun emri altına girersin. Sen başkasının zoruyla bir şeyler yapmaya başladığın zaman artık özgür değilsin demektir. Bu da demek oluyor ki hayatın güzelliklerinin hiçbirini yaşayamayacaksın."

Öğrencilerin bir kısmı ise toplumda mahalle baskısı yüzünden kendilerini hiç özgür hissetmediklerini ve özgür olmanın zor olduğunu belirtmişlerdir. Bu kategori altındaki öğrenci görüşlerini temsilen 15 ve 21 numaralı kadın öğrencilerin görüşleri sırasıyla aşağıda verilmiştir:

"Herkesin özgür olduğunu söylerler. Doğru aslında herkes özgürdür ya da özgür olmaya çalışıyordur. Kuşlar kadar özgür olmak gelir insanın aklına. Hayatımızda aslında hiç özgür değiliz. Insanların tepkisine göre yaşıyoruz. Onunla gezme laf olur. Onunla konuşma dedikodu çıkar. Şunu giyme adın çıkar. Insanları dışarıda gördükleri gibi yorumlamayı çok seven insanlar var. Farkında olmadan kişinin özgürlüklerini kısıtllyorlar. Fakat bunu gören yok ve halen devam ediyor bu durum."

"Özgürlüğün kısıtlanması tam olarak böyle anlatılabilirdi sanırım. Bir zincirleme var. İstediğin gibi değil de insanların tepkisine göre yaşamalıymışsın gibi sanki. Bu da böyle bir zincirleme oluşturuyor. Aileler çocuklarını hep böyle büyütüyorlar. Şunu yapma şöyle derler, oraya gitme gören olur, şunu giyme laf ederler ve daha bir sürü şey. Sürekli bir kısıtlama ve baskı var. Bu yüzden çocuklar da o şeyleri gizli yapıyorlar. Neden? Sirf elalem laf eder diye. Bundan vazgeçilmelidir. Hiçbir insan mükemmel değildir. Laf edenler bence kıskançlı̆ı̆ından konuşuyorlar. Insan istediğini yapmalıdır. O zincirlemeye girmemelidir. Sonra dönüp baktığında keşke yapsaydım değil de iyisiyle kötüsüyle yapmışım içimde kalmadı demelidir. Insanlar konuşur umursama. Senin hayatın senin kararların."

Yukarıdaki iki alıntıdan kadın öğrencilerin özgürlüklerinin kısıtlanmasından ve cinsiyet ayrımcılığından rahatsız oldukları anlaşılmaktadır. Ergenlik dönemine giren öğrencilerin bu şekilde düşünmeleri gayet doğal bir durumdur. Şema 2'den de görüleceği üzere özgürlük karikatürünü öğrencilerin birçoğu tam kavrayamamıştır. Bu duruma karikatürün sözsüz olması ve öğrencilerin karikatürdeki kuşları tam anlamıyla algılayamamaları neden olmuş olabilir. Öğrencilerin bir kısmı (f:14) ise özgürlük değeriyle ilişkili olmayan yorumlamalar yapmış ve karikatürde verilmek istenen mesajı kavrayamamıştır. Kavram yanılgısı yapan öğrenciler (f:10) ise karikatürü adalet, eşitlik, sorumluluk ve dayanışma değerleriyle açıklamaya çalışmışlardır.

\section{Eşitlik Karikatürüne Ait Bulgular}

Eşitlik değeriyle ilgili karikatüre dair öğrenci yorumları çözümlenmiş ve Şema 3’teki kod ve kategorilere ulaşılmıştır.

Şema 3. Eşitlik Karikatürü Yorumlamalarından Elde Edilen Kodlar ve Kategoriler

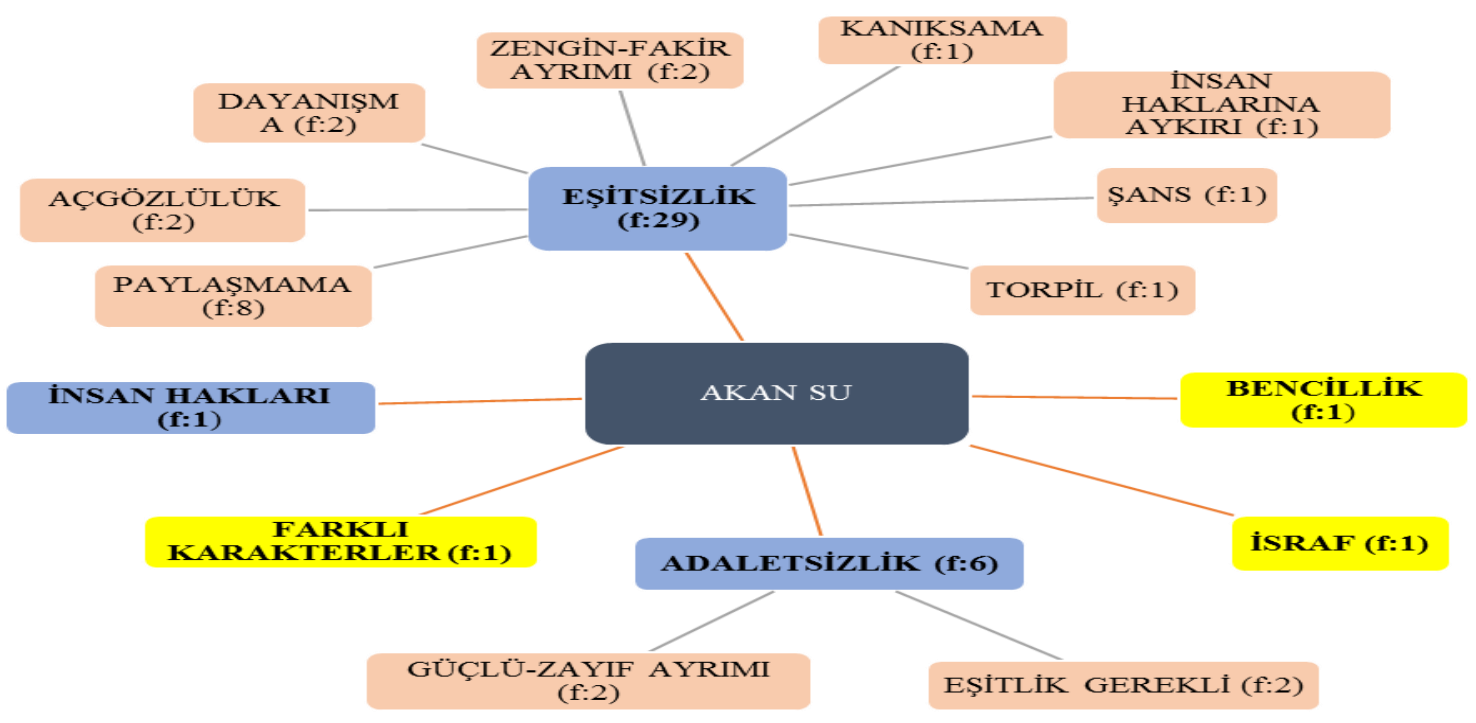


Akan su olarak isimlendirilen karikatürde bir borudan gür bir şekilde akan suyun hepsini şişman adam içerken zayıf ve muhtaç adam ise sadece borudan damlayan su damlacıklarını içmeye çalışmaktadır. Karikatürde dünya kaynaklarının eşit dağıtılmadığı ve insanların açgözlü olup paylaşmayı bilmedikleri vurgulanmaktadır. Şema 3 incelendiğinde karikatüre ilişkin öğrenci yorumlamalarının eşitsizlik, insan hakları, bencillik, israf, farklı karakterler ve adaletsizlik kategorileri altında toplandığı görülmektedir. Eşitlik değeriyle doğrudan ilişkili olmayan kategoriler sarı renkte gösterilmiştir. Öğrenciler karikatürde eşitsizlik yapıldığını anlamış ve bunu kendi açılarından yorumlamışlardır. Öğrenciler dünyadaki eşitsizliği insanların açgözlü olmaları, paylaşmayı bilmemeleri, torpil ve kayırmacılık yapmaları ve zengin-fakir ayrımı yapmaları gibi nedenlere bağlamışlardır. Eşitsizlik kategorisi altında öğrenci görüşlerini temsilen 1 ve 32 numaralı öğrencilerin görüşleri sırasıyla aşağıda verilmiştir:

"Burada ellerinde çok mal olan ve kimseyle paylaşmayan insanlar var ve bir de çok fakir elinde bir şey olmayan insanları temsil ediyor. Çok zengin olanlar elinde çok şeyler olduğu halde hala doymuyorlar. Ama fakir insanlar elinde bir șeyler olmadiğı halde az ile yetinmeye çalışlyorlar. Diğer insanlar açgözlü olmasalar ve fakir insanlara yardım etseler toplum daha çok gelișir ve fakirlerin durumu daha iyi olur. Bundan çıkarılacak sonuç ise durumumuz iyi olsa bile çok şey istememeliyiz ve fakirlere yardım etmeliyiz. Açgözlülük yapmamalıyı."

"Bazı insanlar açgözlülük yaparak insanların haklarını çiğniyor. Kendilerini düşünüp diğerlerini ezerek iyi bir şey yaptıklarını sanıyorlar. Yanındakini birazcık su verse ölür mü? Hayır. Herhangi bir şey kaybeder mi? Hayır. Aslında daha çok kazanır. Yanındakine verince onu mutlu etmiş olur kendisi de mutlu olur. Onunla arasındaki bağ güçlenir. Yardımlaşma duygusu gelişir. Açgözlülük yapıp yanındakine vermediğinde ise haksızlık, eșitsizlik ve kaba bir durum ortaya çıkar."

Yukarıdaki alıntılarda görüldüğü üzere öğrenciler paylaşmanın ve elindekilerle yetinmenin önemine vurgu yapılmıștır. İnsanların toplum içerisinde uyum içinde yașamaları ancak herkesin eşit şartlarda olmasıyla mümkündür. Eşit şartlarda yaşamak insanların elindedir. Bunu başarabilmek için açgözlü olmayıp paylaşmayı öğrenmek gerekmektedir. Bazı öğrenciler ise toplumsal hayattaki eşitsizliği tamamen şansa bağlamaktadır. Bu görüşü temsilen 25 numaralı öğrencinin görüşleri aşağıda verilmiştir:

"Bazı insanlar çok rahat lüks bir hayat sürerken bazı insanlar sefil bir hayat sürebiliyorlar. Günlük hayatımızda resimdeki gibi olayla sık sık karşılaşabiliyoruz. Fakirlik ve zenginlik insanın elinde olan bir durum değildir. Bizler birer Türk vatandaşı olarak bunun bilincinde olmalı ve bu tür durumlar karşısında duyarlı olmalıyı.."

Yukarıdaki ifadelerden bu öğrencinin zengin ya da fakir olmayı tamamen şansa bağladığı görülmektedir. Toplumsal hayatta insanların zengin ya da fakir olmasına bakılmaksızın herkesin eşit şartlarda yaşaması gerekmektedir. Öğrenci; zengin ya da fakir olmanın insanların eşit bir şekilde yaşamasına hiçbir zaman engel olmaması gerektiğini kavrayamamıştır.

Öğrencilerin bir bölümü de karikatürden bencillik ve torpil yapıldı̆̆ı, insan haklarına aykırı bir durum olduğu ve adaletsiz davranıldığı sonuçlarını çıkarmışlardır. Bu görüşleri temsilen 7 numaralı öğrencinin görüşleri aşağıda gösterilmiștir:

"Bu resimde büyük olan yani cüsseli, güçlü olan adam çok su içerken zayıf ve kuvvetsiz olan ise büyük olan adamın artıklarını içiyor. Burada bir eșitsizlik var. Oysaki güce veya başka farklılıklara bakılmadan eșit miktarda su içilmesi gerekiyor. Her insanın haklarına saygı duyulması lazımdır. Insana insan olduğu için saygıda kusur edilmemelidir."

Öğrencilerin ana fikri eşitlik olan karikatürde verilmek istenen mesajı genel olarak anladıklarını söyleyebiliriz. Eşitlik algılarının ortaya konmasında öğrencilerin zengin-fakir ayrımına, paylaşımcı olmaya, insan haklarına, açgözlü olmayıp elindekilerle yetinmeye, toplumsal dayanışmaya ve adalete vurgu yapmaları bu açıdan önemli görülmektedir.

\section{Dayanışma Karikatürüne Ait Bulgular}

Dayanışma değeriyle ilgili karikatüre dair öğrenci yorumları çözümlenmiş ve Şema 4'teki kod ve kategorilere ulaşılmıștır. 
Şema 4. Dayanışma Karikatürü Yorumlamalarından Elde Edilen Kodlar ve Kategoriler

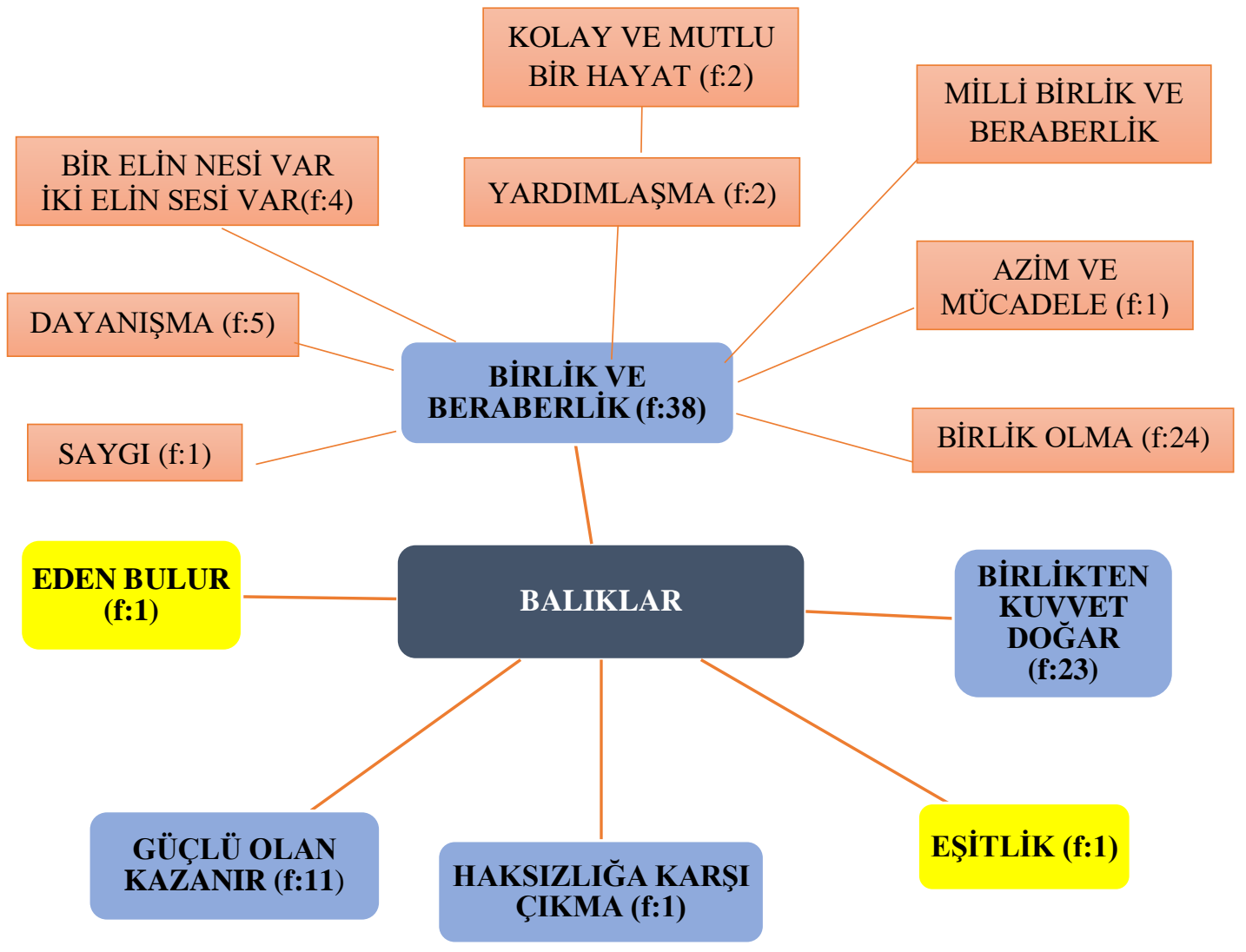

Balıklar ismi verilen karikatür iki bölümden oluşmaktadır. Karikatürün üst kısmında kocaman bir balık tek başına dolaşan küçük balıkları kovalamaktadır. Alt kısımda ise küçük balıklar birlik olarak daha büyük hale gelmiş ve kocaman balığı korkutarak aksi yönde püskürtmüşlerdir. Karikatürde birlik ve beraberlik içerinde hareket edildiğinde her türlü zorluğun üstesinden gelinebileceği anlatılmakta ve dayanışma değerinin önemi vurgulanmaktadır. Şema 4 incelendiğinde öğrenci yorumlarının birlik ve beraberlik, eden bulur, güçlü olan kazanır, haksızlı̆̆a karşı çıkma, eşitlik ve birlikten kuvvet doğar ana kategorileri altında toplandığı görülmektedir. Eşitlik değeriyle doğrudan ilişkili olmayan kategoriler sarı renkte gösterilmiştir. Öğrenciler birlik ve beraberliğin önemine vurgu yaparak dayanışma, azim ve mücadele, yardımlaşma ve karşılıklı saygı değerlerine değinmişlerdir. Karikatürü toplumsal açıdan değerlendiren 19 numaralı öğrencinin görüşleri şu şekildedir:

"Karikatürde birlik ve beraberlik gösterilmek istenmiştir. Büyük balık küçük balığı yer; ama küçük balıklar bir olup büyük balığı yenebilir. Bir toplumda bireyler birbirinden bağımsız hareket ederlerse ve herkesi değiştirirler. Bir olup beraber hareket ederek en güçlüleri bile yenebiliriz. Zulüme karşı koyarız."

Öğrencilerin büyük bir çoğunluğu toplumu oluşturan insanların sorunlar karşısında el ele vermeleri gerektiğini ve güçlerini birleștirdikleri zaman daha büyük işler başaracağını vurgulamışlardır. Birlikten kuvvet doğar kategorisi yorumlamalarda çok sık (f:23) yer almıştır. Bu görüşü temsilen 38 numaralı öğrencinin görüşleri aşağıda gösterilmiştir:

"Büyük balık bir soruna benzetilebilir. Tek başımıza iken sorunu çözmekte zorlanırız; hatta bazen çözemeyiz bile. Ancak birlik olursak her şeyin üstesinden gelebiliriz."

Bazı öğrenciler ise dayanışma değerinden hiç bahsetmemiş ve güçlü olanın her zaman kazandığı doğa düzeninden bahsetmişlerdir. Bu öğrencilerin dayanışma, işbirliği, birlik ve beraberlik değerlerini tam anlamıyla kavrayamadıkları sonucu çıkarılabilir. Öğrencilerin güçlünün zayıfı ezmesini kabullenmeleri ve bu durumu değiştirmek için hiçbir görüş ileri sürmemeleri bu duruma kanıt olarak gösterilebilir. Halbuki karikatürün ikinci kısmında güçlülerin zayıfı ezmemesi 
ve orman kanunlarından ziyade haklının hakkını savunmak için birlik ve beraberlik içinde yardımlaşma değeri vurgulanmaktadır. Öğrencilerin geneli dikkate alındığında karikatürde verilmek istenen mesajın doğru bir şekilde anlaşıldığı ve dayanışma değerinin önemine vurgu yapıldığı görülmektedir.

\section{TARTIŞMA ve SONUÇ}

Adalet değerine ilişkin öğrenci yorumlarına bakıldığında öğrencilerin büyük bölümünün adaletin toplum açısından önemli bir değer olduğunu ve adaletin eşitlikten farklı ve daha iyi olduğunu kavradıkları görülmektedir. Bazı öğrenciler ise adalet değerini eşitlik değeriyle karıştırmışlar ve karikatürü eşitlik temelinde yorumlamışlardır. Karikatürde verilmek istenen asıl mesaj, eşitliğin toplum hayatında her zaman kabul edilebilir bir değer olmadığı ve adaletin sağlanabilmesi için bazen bazı kişilere pozitif ayrımcılık yapılması gerektiğidir. Öğrencilerin \%30'u adalet-eşitlik ayrımını tam kavrayamamıștır. Bazı öğrencilerin ise çalışma kağıdında adalet değerinin özelliklerini anlatmalarına rağmen eşitlik kelimesini kullandıkları görülmüştür. Adalet ve eşitlik birbirini tamamlayan ama birbirinden çok farklı olan demokratik değerlerdir. Eşit olan her durumun adil olmayacağını öğrencilerin kavrayabilmesi bu açıdan önemli görülmektedir. Öğrencilerin adalet değerine yönelik algılamalarının ayrıntılı bir şekilde belirlenebilmesi için öğrencilerle mülakat yapılması daha uygun olacaktır. Adalet değerinin anlamını tam olarak kavrayan öğrenciler; adaletin toplum açısından çok önemli olduğuna değinmiş ve insanlar arasındaki asıl eşitliğin adaletin ișe koşulması sonucunda gerçekleșeceğini belirtmişlerdir.

Özgürlük karikatürüne yönelik öğrenci yorumlamaları çok değişkenlik göstermiştir. Buna göre öğrencilerin yarıdan fazlası özgürlük kategorili karikatürden özgürlük değerini anlamamıştır. Karikatüre yapılan yorumlarda kavram yanılgısına düşen öğrenciler özgürlük karikatürünü adalet, dayanışma, eşitlik ve sorumluluk değerleriyle açıklamışlardır. Bu durum karikatürün sözsüz ve soyut olmasından kaynaklanıyor olabilir. Özgürlük değerine ilişkin öğrenci görüşleri incelendiğinde öğrencilerin kendilerini mahalle baskısı yüzünden özgür hissetmedikleri ve bu durumdan rahatsız oldukları sonucuna varılmıştır. Öğrenciler özgürlüğün önündeki engellerin aşılması gerektiğine inanmaktadırlar. Ergenliğe geçiş döneminde hak, özgürlük ve sorumluluk üçgeninde öğrencilerin özgürlük değerine daha fazla önem vermeleri doğal bir durum olarak karşılanabilir. Nayır ve Akar (2009) tarafından 5. sınıf öğrencileriyle yapılan araştırmada öğrencilerin içgüdülerinin etkisinde gerçekleştirdikleri davranışları özgürlük olarak kabul ettikleri sonucuna varılmıştır. Mevcut araştırmada öğrenciler özgürlük değeriyle ilgili düşünce özgürlüğü ve hayvan hakları kategorilerine dair görüş belirtmişlerdir. Nayır ve Akar (2009) tarafından yapılan araştırmada ise öğrenciler özgürlüğü başkalarına saygı, davranışlarda serbestlik ve bağımsızlık kategorileri altında açıklamışlardır. Mevcut araştırmada öğrenciler özgür olmadan kendi benliklerini bulamayacaklarını belirtmişlerdir.

Eşitlik değerine ilişkin karikatür yorumlamalarından öğrencilerin eșitlik algılarının iki ana eksende dağıldığı görülmektedir. Buna göre öğrencilerin bir kısmı (f:29) eşitlik değerini kavrayarak eşitsizliğin yaşandığı bir toplumun insan haklarına aykırı olduğunu belirtmişlerdir. Öğrenciler toplumda eşitsizliğin nedenini insanların açgözlü olmaları, zengin-fakir ayrımı yapmaları ve paylaşmayı bilmemeleri olarak belirtmektedir. Böyle bir toplumda birlik ve beraberliğin olamayacağını vurgulanmıştır. Elindekilerle yetinmeyen, kendi çıkarları için her türlü bencilliği, adam kayırmacılığı ve torpili yapan insanların eşitlik değerine zarar verdikleri öğrenciler tarafından belirtilmiştir. Bu eksende yer alan öğrenciler toplumdaki eşitsizliğin ana nedeninin insanların kendisinden kaynaklandığının bilincindedirler. Öğrencilerin diğer kısmı (f: 4) ise toplumdaki eşitsizliği tamamen şansa ve kadere bağlayarak bu durumu kanıksamışlardır. Bu eksendeki öğrencilerin eşitliğin insanların kendileri tarafından sağlandığı ve yine insanların şahsi hırs ve menfaatleri baskın geldiği için bozulduğu gerçekliğini tam anlamılla algılayamadıkları görülmektedir. Yılmaz (2013) tarafından 8. sınıf öğrencileriyle yapılan araştırmada öğrencilerin bazılarının eșitlik değeriyle görev ve hak kavramlarını karıştırdıkları sonucuna varılmıştır. Mevcut araştırmada eşitlik değerinin adalet değeriyle karıștırıldığı görülmüştür.

Dayanışma değerine ilişkin öğrencilerin yorumlamalarına bakıldığında öğrenci görüşlerinin iki ana eksende yer aldığı görülmektedir. Öğrencilerin çok büyük bir kısmı zorluklar karşısında 
azim ve mücadele ederek birlik ve beraberlik içinde hareket edilmesi gerektiğini ve birlikten kuvvet doğacağını belirtmişlerdir. Toplum hayatında yardımlaşma ve karşılıklı saygının önemine vurgu yaparak dayanışma içerisinde olunması gerektiğini belirtmişlerdir. Karikatürdeki büyük balığın toplumsal bir soruna benzetildiğinde millet olarak birlik ve beraberliğin öneminin öğrenciler tarafından kavranması bu açıdan önemli görülmektedir. Ersoy (2010) tarafından dördüncü ve beşinci sınıf öğrencileriyle yapılan benzer bir çalışmada, öğrencilerin yarıdan fazlasının karikatürdeki dayanışma mesajını doğru anladıkları görülmüştür. Karikatürler aracılığıyla öğrencilerin bir diğer kısmının güçlü olanın kazanacağı algısına sahip oldukları ortaya çıkmıştır. Bu eksendeki öğrenciler dayanışma, birlik ve beraberlik kavramlarına hiç değinmemişlerdir. Ersoy (2010) tarafından yapılan araştırmada da öğrencilerin \%40'a yakını karikatürden dayanışma değerini anlamamıştır. Dayanışma değeri toplumun birlik ve beraberliği açısından çok önemli bir yere sahiptir. Öğrencilerin karikatürden dayanışma değerinden ziyade güçlü olan kazanır, doğanın kanunu böyledir algısına sahip olmalarının değişik sebepleri olabilir. Soyut düşünme becerisinin tam anlamıly yerleşmemesi ve sosyo-kültürel çevrenin etkisi öğrencilerin bu şekilde düşünmelerine yol açmış olabilir.

$\mathrm{Bu}$ araştırmada öğrencilerin demokratik değer algılarını ortaya koymak amacıyla karikatürlerden yararlanılmıștır. Karikatürlere yapılan yorumlardan adalet, özgürlük, eșitlik ve dayanışma gibi değerlerin öğrencilerde ne anlam ifade ettiği belirlenmiștir. Öğrencilerin demokratik değer algılarının daha ayrıntılı çözümlenmesi amacıyla ileride fenomenolojik araştırmalar yapılması önerilebilir.

\section{KAYNAKÇA}

Ada, S. ve Ünal, S. (2000). Sinıf yönetimi. İstanbul: Marmara Üniversitesi Teknik Eğitim Fakültesi Matbaa Birimi.

Akın, U. ve Özdemir, M. (2009). Öğretmen adaylarının demokratik değerlerinin çeşitli değişkenler açısından incelenmesi: Eğitim Bilimleri Fakültesi örneği. Ankara Üniversitesi Eğitim Bilimleri Fakültesi Dergisi, 42(2), 183-198.

Aydemir, H. ve Aksoy, N, D. (2010). Eğitim fakültesi öğrencilerinin demokratik tutumlarının bazı değisşenlerle ilişkisi: Malatya örneği. Erzincan Eğitim Fakültesi Dergisi, 12(1).

Bacanlı, H. (2006). Duyuşsal davranış eğitimi. Ankara: Nobel Yayın Dağıtım.

Başaran, İ, E. (1986). Demokrat öğrenci nasıl yetiştirilir. Ankara Üniversitesi Eğitim Bilimleri Dergisi, 111-116.

Büyükkaragöz, S. ve Üre, Ö. (1994). Öğretmen yetiştiren yükseköğretim kurumlarındaki öğrencilerin demokratik tutumları araştırması. Türk Demokrasi Vakfı Bülteni. (19), 29-41.

Celep, C. (1995). Demokratik bir eğitim sistemi için. Yaşadıkça Eğitim, 38, 20-24.

Cılga, İ. (2001). Demokrasi insan hakları kültürü ve çocuk hakları. Milli Eğitim Dergisi, 151.

Dewey, J. (2010). Günümüzde eğitim. (Çev. Edt.: Ata, B ve Öztürk, T.). Ankara: Pegem Yayınevi.

Doğanay, A. ve Sarı, M. (2004). İlköğretim ikinci kademe ögrencilerine temel demokratik değerlerin kazandırılma düzeyi ve bu değerlerin kazandırılması sürecinde açık ve örtük programın etkilerinin karşılaştırılması. Kuram ve Uygulamada Eğitim Yönetimi, 39(39), 356-383.

Doğanay, A. ve Sarı, M. (2006). Öğrencilerin üniversitedeki yaşam kalitesine ilişkin algılarının demokratik yaşam kültürü çerçevesinde değerlendirilmesi (Çukurova Üniversitesi Örneği). Türk Eğitim Bilimleri Dergisi, 4(2), 107-128.

Ektem, I. S. ve Sünbül, A. M. (2011). "Öğretmen adaylarının demokratik tutumları üzerine bir araştırma". Selçuk Üniversitesi Ahmet Keleşoğlu Eğitim Fakültesi Dergisi, 31: 159-168.

Erdem, A. R. (2003). Üniversite kültüründe önemli bir unsur: değerler, Değerler Eğitimi Dergisi, 1(4), 25-34.

Ersoy, A. (2010). İlköğretimde Değer kazanımlarının incelenmesinde karikatür kullanımı: dayanışma değeri örneği. Ondokuz Mayıs Üniversitesi Eğitim Fakültesi Dergisi, 29 (2), 79-103.

Givens, S. M. (2010). Using affective assessment to understand our students' identities as readers and nonreaders. Inquiry, 15(1), 5-19.

Gömleksiz, M. N. ve Kan A. Ü. (2008). Eğitim fakültesi ve tezsiz yüksek lisans programlarına kayıtlı öğretmen adaylarının demokratik tutumlarının değerlendirilmesi (Fırat Üniversitesi Örneği). Milli Eğitim Dergisi, 178: 44-63

Güven, A. ve Akkuş, Z. (2004). Demokratik değer kazanımında okulların rolü. Kazım Karabekir Eğitim Fakültesi Dergisi, Sayı: 9.

Hotaman, D. (2010). “Demokratik eğitim: demokratik bir eğitim programı”. Kuramsal Eğitimbilim, 3(1), 29-42

Hökelekli, H. (2010). Modern eğitimde yeni bir paradigma: değerler eğitimi. Eğitime Bakış Dergisi, 6 (18), 410 . 
İlğan, A., Karayiğit, D. ve Çetin, B. (2013). Ortaokul öğrencilerinin demokratik değerlere sahip olma düzeylerinin çeşitli değişkenlere göre incelenmesi. Celal Bayar Üniversitesi Sosyal Bilimler Dergisi, $11(2)$.

Kaldırım, E. (2003). İlköğretim 8.sınıf öğrencilerinin demokrasi algıları. Yayımlanmamış yüksek lisans tezi, Gazi Üniversitesi, Eğitim Bilimleri Enstitüsü, Ankara.

Karadağ, E., Baloğlu, N. ve Yalçınkayalar, P. (2006). İlköğretim okulu yöneticilerinin öğretmenler tarafından algılanan demokratik tutumları ile öğretmenlerin demokratik değerleri üzerine ilişkisel bir araştırma. Değerler Eğitimi Dergisi, 4 (12), 65-82.

Karakütük, K. (2001). Demokratik laik eğitim (çağdaş toplum olmanın yolu). Ankara: Anı Yayıncılık.

Kaya, M. (2006). İlköğretim 8. sınıf Vatandaşlık ve İnsan Hakları Eğitimi dersinde yer alan kavramların kazanılmışlık düzeyi. Yayınlanmamış yüksek lisans tezi, Gazi Üniversitesi Eğitim Bilimleri Enstitüsü, Ankara.

Kıncal, R. ve Işık, H. (2003). Demokratik eğitim ve demokratik değerler. Eğitim Araştırmaları, 3(11), 54-58.

Kışlalı, A. (1994). Kemalizm, laiklik ve demokrasi. (2.basım). Ankara: İmge Kitapevi.

Kulaksızoğlu, A. ve Dilmaç, B. (2000). İnsani değerler eğitim programı. Marmara Üniversitesi Atatürk Eğitim Fakültesi Eğitim Bilimleri Dergisi, 12, 199-208.

Maxwell, J.A. (2008). Qualitative reseach design: an interactive approach. London: Sage.

McNeill, B, Burrows, V. and Bellamy, L. (2000). Including affective behavior in course grades, ASEE - PSW Section, Spring. Conference, Tucson AZ.

Miles, M. B. \& Huberman, A. M. (1994). Qualitative data analysis: an expanded sourcebook. (2nd Edition). California: SAGE Publications.

Moller, J. (2006). Democratic schooling in norway: Implications for leadership in practice. Leadership and Policy in Schools, 5 (1), 53-69.

Mulhan, M. (2007). İlköğretim 7. sınıf Vatandaşlık ve İnsan Hakları Eğitimi dersi kavramlarının öğrenilmesinde sosyal, ekonomik ve kültürel faktörler ile eğitim-öğretim uygulamalarının etkileri. Yayınlanmamıș yüksek lisans tezi, Marmara Üniversitesi Eğitim Bilimleri Enstitüsü, İstanbul.

Namlı, Z. (2015). Sosyal bilgiler dersinde değer eğitimi. (Ed: R. Sever). Sosyal Bilgiler Öğretimi. Ankara: Nobel Yayın Dağıtım, 351-375.

Nayır, F., ve Akar, F. (2009). İlköğretim beşinci sınıf öğrencilerine göre özgürlük kavramı ve özgürlüğün ilişkilendirildiği davranıșlar. I. Uluslararası Avrupa Birliği, Demokrasi, Vatandaşlı ve Vatandaşlık Eğitimi Sempozyumu, 216-223.

Okutan, M. (2010). Türk Eğitim Sistemi'nde demokrasi eğitimi. Uluslararası İnsan Bilimleri Dergisi, 7(1).

Özpolat, V. (2010). Bir toplumsal değiş̧me paradigması olarak demokrasinin eğitime yansımaları: demokratik eğitim. Milli Ĕgitim Dergisi,(Kış), (135), 365-381.

Sabancı, O. (2008). İlköğretim 7. sınıf öğrencilerinin sosyal bilgiler dersinde yer alan vatandaşlık konularıyla ilgili kavramsal algıları. Yayınlanmamış yüksek lisans tezi, Gazi Üniversitesi Eğitim Bilimleri Enstitüsü, Ankara.

Sarı, M. ve Sadık, F. (2011). Öğretmen adaylarının demokrasi algıları (Çukurova Üniversitesi Örneği). Uluslararası Eğitim Programları ve Öğretim Çalışmaları Dergisi, Cilt: 1(2).

Sidekli, S., Er, H., Yavaşer, R. ve Aydın, E. (2014). Sosyal bilgiler öğretiminde alternatif bir yöntem: karikatür. Uluslararası Türk Eğitim Bilimleri Dergisi, 2, 151-163.

Singh, K. (2007). Qualitative research methods. London: Sage

Tanilli, S. (1995). Nasil bir demokrasi istiyoruz? İstanbul: Cem Yayınevi.

Toomey, R. (2010). Values education, instructional scaffolding and student wellbeing. T. Lovant, R. Thoomey ve N. Clements (Eds,), International research handbook on values education and student wellbeing. (1936). Newyork: Springer Netherlands.

Türk Dil Kurumu (1998). Türkçe sözlük. Ankara: Türk Tarih Kurumu Yayınları.

Ural, S, N. ve Sağlam H, İ. (2011). İlköğretim öğrencilerinin demokratik tutum düzeylerinin bazı değişkenler açısından incelenmesi. Değerler Eğitimi Dergisi, Cilt:9 No: 22, 161-180.

Uslu, H. (2007). Eğitimde karikatür. Bilim ve Aklın Aydınlı̆ı̆nda Eğitim, 84 (7), 15-18.

Uygun, S. ve Engin, G. (2014). Temel Demokratik Değerler Ölçeği: Bir Ölçek Geliştirme Çalışması. Turkish Studies - International Periodical For The Languages, Literature and History of Turkish. Volume 9/5 Spring, p. 2021-2031, http://www.turkishstudies.net/english/DergiPdfDetay.aspx?ID=6660

Yazıcı, K. (2006). Değerler eğitimine genel bir bakış. Türklük Bilimi Araştırmaları, 19, 499-522.

Yazıcı, K. (2011). Sosyal bilgiler öğretmen adaylarının demokratik değerlerinin çeşitli değişkenler açısından incelenmesi. Eğitim ve Bilim, Cilt 36, Sayı 159.

Yeşil, R. (2002). Okul ve ailede insan hakları ve demokrasi eğitimi. Ankara: Nobel Yayıncılık.

Yeşil, R. (2003). "Demokratik eğitim ortamının insan hakları temeli", Gazi Üniversitesi Kırşehir Eğitim Fakültesi Dergisi, 4(2) 45-54. 
Yeşil, R. ve Aydın, D. (2007). Demokratik değerlerin eğitiminde yöntem ve zamanlama. Türkiye Sosyal Araştırmalar Dergisi, 11(2), 65-84

Yıldırım, A. ve Şimşek, H. (2013). Sosyal bilimlerde nitel araştırma yöntemleri. (9. Baskı). Ankara: Seçkin Yayıncilık

Yılmaz, K. (2013). İlköğretim öğrencilerinin vatandaşlık eğitimi ile ilgili temel kavramlara ilişkin algılarının incelenmesi. Hacettepe Üniversitesi Ĕ̆itim Fakültesi Dergisi, 28(1), 453-463

Yüksel, İ., Bağcl, Ş. ve Vatansever, E. (2013). İlköğretim son sınıf öğrencilerin demokratik değerlere sahip olma düzeylerinin belirlenmesi. Adıyaman Üniversitesi Sosyal Bilimler Enstitüsü Dergisi, 6(12), 309-334. 